\title{
Lexis
}

Journal in English Lexicology

2 | 2008

Lexical Submorphemics

\section{Submorphemic iconicity in the lexicon: a diachronic approach to English 'gn- words'}

\section{Dennis Philps}

\section{(2) OpenEdition}

Journals

\section{Electronic version}

URL: http://journals.openedition.org/lexis/728

DOI: $10.4000 /$ lexis.728

ISSN: 1951-6215

\section{Publisher}

Université Jean Moulin - Lyon 3

\section{Electronic reference}

Dennis Philps, "Submorphemic iconicity in the lexicon: a diachronic approach to English 'gn- words' », Lexis [Online], 2 | 2008, Online since 10 November 2008, connection on 21 April 2019. URL : http:// journals.openedition.org/lexis/728; DOI : 10.4000/lexis.728

\section{c) (i) $९$}

Lexis is licensed under a Creative Commons Attribution-NonCommercial-NoDerivatives 4.0 International License. 


\title{
Submorphemic iconicity in the lexicon: a diachronic approach to English ' $g n$ - words, ${ }^{\text {,161 }}$
}

Dennis Philps ${ }^{162}$

\begin{abstract}
By applying a principle of submorphemic invariance to the word-initial segment gn(phonologically $/ \mathrm{n} /$ ) in the heuristic class of English ' $g n$ - words', I show that this segment functions as a 'sublexical marker' $(<$ gn $->)$, defined as a semiologically and notionally invariant submorphemic unit within the subset(s) of words of which it is a formative. I go on to claim, based on evidence provided by phononotional $G N-/ G V N(-)$ alternation, that although $<$ gn- $>$ must be considered as structurally indivisible in Modern English, $<\mathrm{g}>$ in $<$ gn- $>$ may originally have functioned as a 'core invariant' and $<$ n $>$ as a variable in the prehistory of English, specifically in Proto-Indo-European. Analysing gn- in most ' $g n$ - words' of Anglo-Saxon origin and some of Greek origin as the surface trace of an underlying notional domain linked to jaw-related phenomena (sound articulation, mastication, manducation, etc.) suggests that there exists an extralinguistically motivated, causal relation between $<$ gn- $>$ and this domain involving the concept of 'submorphemic iconicity'.
\end{abstract}

Keywords: $\quad$ submorphemic iconicity — sublexical marker - 'gn- words' — invariance notional domain

$* * *$

\section{Résumé}

L'application d'un principe d'invariance submorphémique au segment initial gn(phonologiquement /n/) dans la classe heuristique des 'mots en $g n$-' de l'anglais nous permet de montrer que ce segment fonctionne comme un 'marqueur sub-lexical' (<gn- $>$ ), défini comme une unité submorphémique douée d'une invariance tant sémiologique que notionnelle au sein du sous-ensemble de mots dont il est un élément formateur. Nous émettons l'hypothèse, fondée sur l'existence d'une alternance phono-notionnelle $G N-/ G V N(-)$, que bien que $<$ gn- $>$ semble être structurellement indivisible en anglais moderne, $<$ g $>$ dans $<$ gn- $>$ a pu fonctionner comme 'invariant-noyau' et $<\mathrm{n}>$ comme variable à date préhistorique, et tout particulièrement en indo-européen commun. En analysant gn- dans la plupart des 'mots en $g n$-' d'origine anglo-saxonne et dans certains vocables d'origine grecque comme étant la trace en surface d'un domaine notionnel lié aux phénomènes temporomandibulaires (articulation de sons, mastication, manducation, etc.), nous sommes amené à formuler l'hypothèse qu'il existe une motivation extralinguistique, de nature causale, entre $<$ gn- $>$ et ce domaine qui intègre le concept $d$ ' « iconicité submorphémique ».

\footnotetext{
${ }^{161}$ I would like to express my grateful thanks to two anonymous readers for their comments on an earlier version of this paper.

${ }^{162}$ Université de Toulouse-Le Mirail (France).
} 
Mots-clés : iconicité submorphémique - marqueur sub-lexical - 'mots en gn-' invariance - domaine notionnel 


\section{Introduction: from phonæstheme to sublexical marker}

Phonæsthemes (Firth 1930) are frequently recurring, systematic pairings of form and meaning in the lexicons of many languages, including English. Their morphological status is probably best characterized as 'submorphemic', if one accepts Crystal's definition of a submorpheme as 'a part of a morpheme that has recurrent form and meaning, such as the $s l$ beginning of slimy, slug, etc.' (Crystal 2003: 301). It may be argued that phonæsthemes have submorphemic status because they do not combine with morphemes to form words, but with submorphemes (e.g. sn- + -iff $>$ sniff), while morphemes either form words themselves, or combine with other morphemes to do so by means of morphological processes such as inflection, derivation, and compounding. However, this status is the subject of ongoing debate (see Bloomfield 1933: 245, Bolinger 1950: 130, Bergen 2004: 290, etc.). The application of principles of invariance to phonæsthemes has led me to reanalyse them as 'sublexical markers', defined as semiologically and notionally invariant submorphemic units within certain subsets of the word classes in which they occur ('sn- words', etc., see Philps 2002), and noted between chevrons ( $<$ sn- $>$, etc.).

In this paper, I shall start by setting up a heuristic class I call ' $g n$ - words', on the basis of a structural analysis of the $G N V C(-)$ lexical schema assumed to underlie the stems of these words. This class comprises all and only those lexical items that begin with gn-, phonologically $/ \mathrm{n} / \mathrm{in}$ Modern English. I shall then look at phononotional $C R-/ C V R(-)$ alternation, e.g. $b r-/ b V r(-)$ in bring / bear (common notion: 'carrying'), before going on to examine one particular sublexical marker, the analysis of which poses the problem of the link between semiological invariance and phonological invariance, namely $<$ gn- $>$. I use the term 'phononotional' to denote frequently recurring, systematic pairings of form and notion at submorphemic level.

Few scholars have attributed phonæsthemic status to gn- in English 'gn- words', possibly because it is no longer pronounced as a cluster in Modern English, along with the fact that studies relating to phonæsthemes often have a synchronic bias. However, it is empirically verifiable that most ' $g n$ - words' of Germanic origin and some etymologically unrelated ' $g n$ words' of Greek ancestry have meanings referring to jaw-related phenomena such as the manner of articulating sounds (e.g. dial. gnatter 'to grumble, complain' [grumble (v.) 'to utter dull inarticulate sounds', $O E D^{163}$ ], mastication (e.g. gnaw 'to bite...'), and manducation (e.g. dial. gnip 'to eat'), as shown in fig. 1, which will serve as our corpus.

\begin{tabular}{|c|c|c|}
\hline 'gn- words' & Meaning(s) & Source \\
\hline gnag & 'to gnaw, bite hard at something, nibble, tear, bite' & $E D D^{I / 164}$ \\
\hline gnap & 'to bite in a snapping fashion' & $O E D$ \\
\hline gnarl & 'to snarl' & $O E D$ \\
\hline $\operatorname{gnar}(r)$ & 'to growl, snarl, like an angry dog or beast; (fig.) to quarrel' & $E D D^{I I}$ \\
\hline gnash & 'to strike together or 'grind' the teeth; to bite upon' & $O E D$ \\
\hline gnat & 'any of numerous small mostly biting dipteran insects...' & $\begin{array}{l}\text { NSOED } \\
165\end{array}$ \\
\hline gnathic & 'of or pertaining to the jaws' & $O E D$ \\
\hline gnatter & 'to gnaw, bite at anything hard, nibble; to grumble, complain' & $E D D^{I I}$ \\
\hline
\end{tabular}

${ }^{163}$ The Oxford Dictionary of English, $2^{\text {nd }}$ edition, 1989.

${ }^{164}$ The English Dialect Dictionary (Wright 1898-1905).

${ }^{165}$ The New Shorter Oxford English Dictionary, 1993 edition. 


\begin{tabular}{|l|l|l|}
\hline gnaw & 'to bite (something) persistently...' & OED \\
\hline gnibble & 'to take little bites of (a thing)...' & $O E D$ \\
\hline gnip & 'to eat; to complain constantly about' & $E D D^{I I}$ \\
\hline
\end{tabular}

Fig. 1: English 'gn- words' denoting jaw-related phenomena

The fact that some ' $g n$ - words' do not denote jaw-related phenomena may be explained in part by what Bolinger (1949) calls 'cross-influence', i.e. analogically driven blending, as in the case of gn- and $s n$ - words from Proto-Germanic onwards, e.g. gnarl 'to contort, twist...' $<* g(e) n$ - 'to compress into a ball' (Watkins 2000: 26) / snarl 'tangle, twist together confusedly' $<*(s)$ ner- 'to wind, twist' (Pokorny 1959: 975), and in part to the fact that they derive from PIE roots which do not convey jaw-related notions (e.g. gnosis $<$ Gk. gnôsis < PIE * gneh $3^{-}$'to know').

Finally, I shall attempt to determine whether $<$ gn- $>$, like $<$ sn- $>$ (Philps 2002), contains a core invariant, and will invoke the concept of 'submorphemic iconicity' (see Bottineau 2003 for that of 'semantic iconicity') to account for the invariant notional domain apparently vectored by $g n$ - in the subset of ' $g n$ - words' in question.

\section{Phononotional $C R-/ C V R(-)$ alternation}

If words beginning with $g n$ - are set up heuristically as a 'class', and if derivational phenomena are set aside (e.g. gnag > gnaggle 'to gnaw, bite at anything hard', $E D D^{I I}$ ), then the members of this small class may be represented schematically as having an underlying $G N V C(-)$ structure (where $V=$ any possible vowel, $C=$ any possible consonant, and (-) = suffixable), since all ' $g n$ - words' have stems that conform to this schema. In the various realizations of $G N V C(-),-V$ - can be long, e.g. in dial. gneep 'a foolish fellow' $\left(E D D^{I I}\right)$, short, e.g. in gnat, or a diphthong, e.g. in gneiss; if $-V$ - is long, $-C$ can be $\varnothing$, e.g. in Standard English gnaw.

It may then be posited that any formal difference attested by the 'rime' (Bolinger 1950) results from a transformation operating on the variable segment of the GNVC(-) lexical schema $(-V C)$ when realized, while $G N$ - remains invariant insofar as it is the defining condition of the class. The segment $-V C$ is analysed as a variable segment in $G N V C(-)$ on the basis that when gnap and gnip ${ }^{166}$ for instance, are opposed, the transformation in question modifies $-V$-; when gnat and gnap are opposed, it modifies $-C$, and finally, when gnat and gnip are opposed, it modifies both $-V$ - and $-C$ (see fig. 2 below).

\footnotetext{
${ }^{166}$ Gnap (v.) 'to gnaw, bite at, nibble, snap at'; gnip (v.) 'to eat' $\left(E D D^{I I}\right)$.
} 


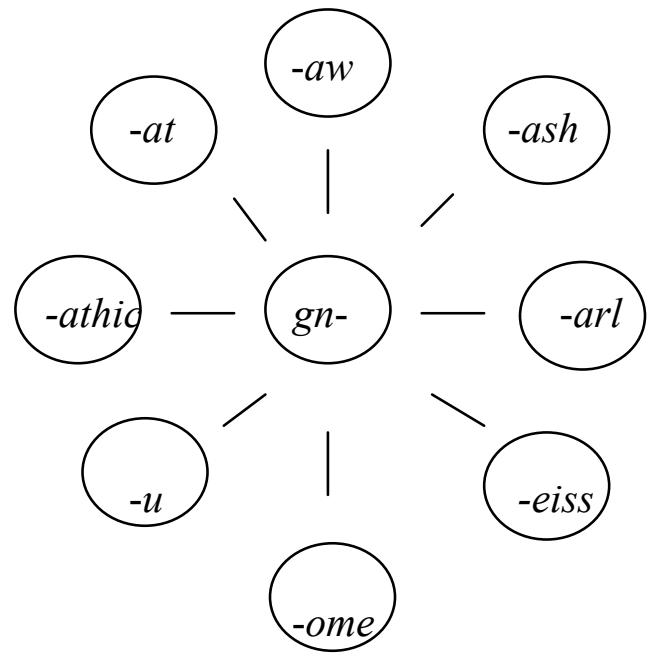

Figure 2: Structural invariance and variability in ' $g n$ - words'

In word-initial position, there are two major types of consonant segments considered to be phonæsthemes in English: $S C$ - segments (sl-, sn-, sp-, $s w$-, etc.), ${ }^{167}$ and $C R$ - segments ( $b r-, f l$ , $g l$-, tr-, etc.). ${ }^{168}$ Now I have shown elsewhere (Philps 2002) that in certain subsets of the phonæstheme $s n$-, $C$ - functions as a 'core invariant', defined as the smallest structural unit within a given subset of a given class of words to which a common notion may be attributed, and $s$ as an initial variant. This analysis is based on the fact that the presence $([+\mathrm{s}])$ or absence ([-s]) of $s$ - in phonosemantic 'sn-/n-doublets' such as sneeze / neeze (dial.) or sniff / niff (fam.) does not modify the basic meaning, as may be seen in fig. 3 below.

\begin{tabular}{|c|c|c|}
\hline $\begin{array}{l}\text { Phonosemantic } \\
\text { 'sn- doublets' }\end{array}$ & Principal meaning of $[+s]$ form & Principal meaning of $[-s]$ form \\
\hline snag/nag & $\begin{array}{l}\operatorname{snag}\left(\mathrm{v}^{2} .\right): \text { 'to snap, bite' } \\
\left(E D D^{V}\right)\end{array}$ & $\begin{array}{l}\text { nag (v.) 'to gnaw, nibble' (OED); } \\
\text { 'to bite' }\left(E D D^{I V}\right)\end{array}$ \\
\hline snar/narr & $\begin{array}{l}\text { snar (v.) 'of a dog: to snarl, growl' } \\
(O E D)\end{array}$ & $\begin{array}{l}\text { narr (v.) 'of dogs, etc.: to snarl or } \\
\text { growl' }(O E D)\end{array}$ \\
\hline sneeze/neeze & $\begin{array}{l}\text { sneeze }(\mathrm{v}) . \text { 'to drive or emit air or breath } \\
\text { suddenly through the nose and mouth...' } \\
(O E D)\end{array}$ & $\begin{array}{l}\text { neeze }(\mathrm{v} . \text { dial. })=\text { sneeze }(\mathrm{v} .) \\
(O E D)\end{array}$ \\
\hline sniff/niff & $\begin{array}{l}\text { sniff }(\mathrm{v} .) \text { 'to draw air through the nose } \\
\text { with short or sharp audible inhalations' } \\
(O E D)\end{array}$ & $\begin{array}{l}\text { niff (v.) 'to have a disagreeable } \\
\text { smell' }(O E D)\end{array}$ \\
\hline snob/nob & $\begin{array}{l}\left.\text { snob (n. }{ }^{1}\right) \text { 'one who wishes to be } \\
\text { regarded } \\
\text { as a person of social importance' (OED) }\end{array}$ & $\begin{array}{l}\text { nob }\left(\mathrm{n} .^{3}\right) \text { 'a person of some social } \\
\text { distinction' }(O E D)\end{array}$ \\
\hline
\end{tabular}

\footnotetext{
${ }_{167}$ Where $S=s$ and $C=$ voiceless occlusive [an older word for 'plosive', Trask (1996)], or resonant.

${ }^{168}$ Where, simplifying a little, $C=$ voiced occlusive, voiceless occlusive, voiceless fricative, or $\varnothing(/ \mathrm{g} / \mathrm{in} / \mathrm{gn} / \mathrm{or}$ $/ \mathrm{k} / \mathrm{in} / \mathrm{kn} /$ in Modern English), and where $R=$ resonant.
} 


\begin{tabular}{|l|l|l|}
\hline snuzzle/nuzzle & $\begin{array}{l}\text { snuzzle (v. dial.) 'of a dog: to sniff or } \\
\text { poke with the nose' }(O E D)\end{array}$ & $\begin{array}{l}\text { nuzzle (v. }{ }^{1} \text { ) 'to poke or push with } \\
\text { the nose' }(O E D)\end{array}$ \\
\hline
\end{tabular}

\section{Figure 3: Dictionary definitions of phonosemantic 'sn-/n- doublets' Sources: $O E D, E D D$}

The above analysis is inspired by the French linguist Gustave Guillaume (1883-1960), who hypothesized that 'the various contextual senses of a morpheme arise as actualized meanings from a single potential meaning' (Hirtle, in Guillaume 1984: XII; see also Hirtle 2007: 21-22). Guillaume saw the causal distinction between condition and consequence as the universal principle governing the construction of all languages: "[T]he linguistic sign establishes an invariant condition in tongue [Fr. 'langue'] from which there develops an infinite number of consequences" (1964: 150, my translation).

Transposing these hypotheses to the submorphemic level allows one to show that invariant word-initial phonæsthemes such as $s n$ - in 'sn- words' and, as I argue here, $g n$ - in ' $g n$ - words', are endowed with a potential for meaning. This potential can only be realized linguistically once the underlying notion vectored by the invariant submorpheme, e.g. jawrelated phenomena in one subset of ' $g n$ - words', is particularized by submorphemic accretion to such a degree that it attains meaningful status, e.g. $g n-+-a w \rightarrow$ gnaw. $C R$ - segments, on the other hand, require an approach which differs in one respect from that applied to $S C$ segments, in that they display phononotional $C R-/ C V R(-)$ alternation rather than phonosemantic $S C$-/C- alternation, as may be observed in fig. 4 below.

\begin{tabular}{|c|c|}
\hline $\begin{array}{c}C R- \\
\text { segments }\end{array}$ & Doublets / Common notion \\
\hline$b l-(/ b l /)$ & $\{$ blare / bawl (v./v.), shouting $\}$ \\
\hline$b r-(/ \mathrm{br} /)$ & $\{$ bring / bear (v./v. $)$, carrying $\}$ \\
\hline$c l-(/ \mathrm{kl} /)$ & $\{$ clamour / call $(\mathrm{v} .1 / \mathrm{v})$, shouting $\}$ \\
\hline$c r-(/ \mathrm{kr} /)$ & $\left\{\operatorname{crêpe} / \operatorname{curl}\left(\mathrm{v} . / \mathrm{v} .{ }^{1}\right)\right.$, curling $\}$ \\
\hline$d r-(/ \mathrm{dr} /)$ & 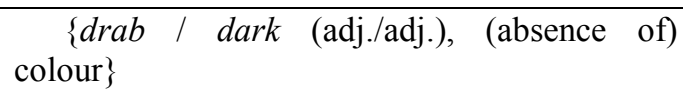 \\
\hline$f l-(/ \mathrm{fl} /)$ & \{flame / fulgent (n./adj.), brillance $\}$ \\
\hline$f r-(/ \mathrm{fr} /)$ & $\{$ front / fore (n./n.), anteriority $\}$ \\
\hline$g l-(/ g 1 /)$ & $\left\{\right.$ glut / gullet (n. ${ }^{2} / \mathrm{n}$.), swallowing $\}$ \\
\hline$p l-(/ \mathrm{pl} /)$ & $\left\{\right.$ plane / pallet $\left(\mathrm{n} .{ }^{3} / \mathrm{n}^{3}\right)$, flatness $\}$ \\
\hline$p r-(/ \mathrm{pr} /)$ & $\{$ prime / paramount (adj./adj.), superiority\} \\
\hline $\operatorname{tr}-(/ \mathrm{tr} /)$ & $\left\{\operatorname{tree} / \operatorname{tar}\left(\mathrm{n} . / \mathrm{n} .{ }^{1}\right)\right.$, wood $\}$ \\
\hline
\end{tabular}

Fig. 4: Phononotional $C R-/ C V R(-)$ alternation Source: $O E D$

By envisaging sublexical markers as surface traces of general underlying notions, one is able to attribute a 'notional' value to these markers within the subsets in which they occur, e.g. $\{(s) n$-, nasality $\}$ in that subset of 'sn- words' including snaffle, sneeze, sniff, snob, snore, etc., or $\{g r$-, prehension $\}$ in that subset of ' $g r$ - words' including grab, grapple, grip, grope, grub, etc. Within the present framework, a 'notion' is envisaged as a conceptual space which 
may be defined as a set of complex mental representations resulting from the mind's attempts to categorize experience, notably the formal, functional and compositional properties of the latter. These attempts are necessarily conditioned by human subjectivity, culture and convention.

Seen in this light, notions may be analysed following principled cognitive criteria into 'notional domains', noted between slashes (e.g. /nasality/), to which a metric may be applied (Culioli 1990: 69). Such domains are topologically constrained, insofar as they can be identified interactively in terms of an interior (I) and an exterior (E) separated by a boundary (B) which is flexible and permeable. Furthermore, they may be organized hierarchically on the basis of dimensional, meronymic, and other relational criteria. For instance, a notional domain may be a superordinate conceptual space ( $\Sigma$ sup) including several subordinate spaces $(\Sigma$ suba...n), while $\Sigma$ sup itself may be subordinated to a superordinate space ( $\Sigma$ SUP).

The domain of particular interest to us here, that of jaw-related phenomena, has been set up heuristically on the basis that it is a salient conceptual space located within the superordinate domain of the human body, and encompasses several subordinate domains, e.g. the jaws, the chin ['the front of the lower jaw'], the mouth and the teeth, as well as the topological, functional and expressive properties - both articulatory and gestural-associated with these subordinate domains. As Ladefoged recalls, movements of vocal organs, which he conceives of as gestures, are controlled and purposeful; in particular, the movements of jaw and tongue are interlinked:

The principal muscle of the tongue is the genioglossus, which pulls the back and root of the tongue towards the front of the mandible (the jawbone). The net effect of contracting the genioglossus muscle is that the tongue gets compressed within the jaw. (Ladefoged 2005: 125)

\section{The sublexical marker <gn->}

While the orthographical forms of word-initial $S C$ - segments always correspond to the word-initial phonological structure /SC/ in English (e.g. $s n_{-}=/ \mathrm{sn} /, s p-=/ \mathrm{sp} /, s w_{-}=/ \mathrm{sw} /$ ), this is not always the case with $C R$ - segments, since although $b l$ - corresponds to $/ \mathrm{bl} /$ and $g r$ - to /gr/, for instance, the orthographical form gn- no longer corresponds to the word-initial phonological structure /gn/ as it did in earlier stages of the language (Dobson 1968: 977978), but to /n/: the form gnaw, for example, is pronounced /n๊:/ in late Modern English. Indeed, Jespersen has referred to initial $g n$ - as a 'consonant group' which has become 'lightened' (1994: 4), while other linguists have examined the reduction of initial $\mathrm{kn}$ and $\mathrm{gn}$ to /n/, e.g. Kökeritz (1945), Dobson (1968), and Lutz (1992). A distinction must therefore be maintained between the synchronic and the diachronic status of these markers.

As seen above, it is possible to bring into focus relations between certain members of the class of ' $g n$ - words' and ' $g V n(-)$ words' which would otherwise remain unobserved or appear fortuitous, by adopting a more abstract representation of these classes. This is accomplished by setting up underlying lexical schemas, e.g. $G N V C(-)$ and $G V N(-)$, remembering that different phonetic and phonological constraints (initial consonant reduction, vowel length, diphthonging, absence of a final consonant, variations due to rhoticity, etc.) apply to their respective realizations. One such relation is that between ' $g n$ - words' and ' $g V n(-)$ words' denoting jaw-related phenomena (mastication, manducation, manners of speaking, expressive gestures, etc.). Two schemas are involved here: $G N V C(-)$, as in gnathic (adj.) 'of or pertaining to the jaws', and $G V N(-)$, as in genial (adj. ${ }^{2}$ in $O E D$ ) in the anatomical sense of 'of 
or pertaining to the chin'. The 'gn- words' of Anglo-Saxon stock concerned, most of which are probably late analogical innovations, are often described as 'onomatopœic' and are of uncertain etymology. They may be assumed to continue Proto-Germanic *gn- roots', the Indo-European forms of which are usually given as 'hypothetical', e.g. * $g h(e) n$ - $>$ ProtoGerm. *gnagan (> OE gnagan > Mod. Eng. gnaw, Watkins 2000: 29).

It should be noted that $<\mathrm{gn}->$ must, in certain circumstances, be analysed in conjunction with the sublexical marker $<\mathrm{kn}->$, represented semiologically by $k n-$, which is also realized as /n/ in Late Modern English (e.g. knee: /ni:/). This is because certain English ' $k n$ - words' continue *gn- clusters in PIE, e.g. knee $<\mathrm{OE}$ cnēo $<$ Germanic *knewam $<$ PIE * $\hat{g} n e u$-, base II of * $\hat{g} e n u$ - 'knee'. This root is also continued in English, via Latin, by genuflect, reflecting the lexical schema $G V N(-)$, but additionally by knop 'the rounded protuberance formed by the front of the knee or the elbow-joint' and knuckle (< Germ. *knapp- and *knukrespectively), both of which appear to derive from, or at least to be modelled on, the hypothetical $* g(e) n-$.

As previously mentioned, the phonetic realization of $G$ in the lexical schema $G N V C(-)$ may not be instantiated in a given state of the language, due to the consequences of phonetic change. In 'gn- words' of Anglo-Saxon origin, for instance, the devoicing and eventual loss of the word-initial voiced velar occlusive appears to have begun during the Middle English period, judging by the dates of the earliest attestations provided by $O E D$. For instance, gnat $(<\mathrm{OE}$ gncet $(t))$, one of the rare ' $g n$ - words' of Old and Middle English not to have undergone $s$ - accretion (Philps 2003), was spelt knatt(e) in the course of the $14^{\text {th }}$ century. This reduction affected educated speech as early as the $16^{\text {th }}$ century, according to Dobson:

\footnotetext{
Initial [gn] had two developments which affected educated speech in the sixteenth and seventeenth centuries. In the first the [g] was lost by a direct process of assimilation to [n] [...]. In the second, $[\mathrm{gn}]$ by dissimilation becomes $[\mathrm{kn}][\ldots]$; thereafter it develops with original $\mathrm{kn}$ through $[\chi n]$ and $[\mathrm{hn}]$ to [n*] and [n]. (1968: 977-8)
}

To exemplify the first development ([gn] $>[\mathrm{n}])$, Dobson quotes sources of the period ('homophone' pairings, etc.) which suggest that gnash had become nash, gnat $>$ nat, and gnaw $>$ naw, while the second development $([\mathrm{gn}]>[\mathrm{kn}]>[\mathrm{n}])$ is testified to by lists or pairings including gnat $>$ knat and gnaw $>$ knaw.

\section{Core invariance and English $<$ gn- $>$}

One consequence of the phonotactically-driven reduction of $/ \mathrm{gn} /$ to $/ \mathrm{n} /$ for the diachronic analysis of $\langle$ gn- $>$ is that, contrary to $<$ n $>$ in $<$ sn- $>,<$ n $>$ in $<$ gn- $>$ cannot be analysed as a core invariant, since gnag, knag, and nag, for example, are diachronic evolutions of the same word, whereas sneeze and neeze, for instance, are different words (sneeze is first attested c1493 as replacing OE fnese, while neeze, from ON hnjósa, is attested earlier, c1340, indicating that it is not the result of consonant reduction affecting $s n-)$. Hence phonosemantic $g n-/ k n$-/øn- alternation cannot be equated with phonosemantic $s n$-/øn- alternation. Also, there

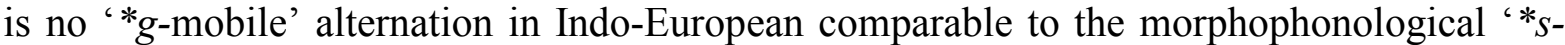
mobile' alternation on which the phonosemantic sn-/øn- 'doublets' in English (sniff / niff, etc.) and other Germanic languages are modelled (Southern 1999: 70-71). Phonosemantic 
'doublets' such as gnar(r) (v., dial.) 'to snarl, growl' / narr (v., dial.) 'of a dog: to snarl, growl' must therefore have a different structural origin.

In fig. 5 below, I have set up a class of ten lexical items (' $g V C(-)$ words'), based on the heuristic criteria that all correspond to the lexical schema $G V C(-)$ subsuming $G V N(-)$, and that all have meanings referring to jaw-related phenomena in either their nominal or their verbal uses, or both: parts of the anatomy (mouth, teeth, jaws, chin, gums...), expressive facial activities (opening the mouth, showing the teeth, gaping...), functional activities (biting, swallowing, breathing...), etc., in human and non-human animates. Within this class, three items correspond to the schema GVN(-): gan, gen and gen(-) in genial, while the others correspond respectively to GVB(-) (gob), GVL(-) (gill), GVM(-) (gam, gum), GVP(-) (gape), and GVR(-) (gur- in gurgitate). Given that the invariant segment in this class appears to be $G$-, since $-V$ - and $-C$ - are both variables, I will hypothesize that $G$ - functions as a core invariant $(<\mathrm{g}>)$ here, as it corresponds to the smallest structural unit within the class of ' $g V C(-)$ words' in fig. 5 to which the jaw-related notional domain common to all its members may be attributed.

Support for this analysis is provided indirectly by the fact that substituting other possible consonants for $g$ - in the class of ' $g V n(-)$ words' (e.g. : $p$-: pen, $t$-: tan, $l-:$ line, $m$-: man, etc.), does not allow one to identify a common notional domain other than fortuitously (e.g. dental (adj.) 'of or pertaining to the teeth...' (OED) and mental (adj. ${ }^{2}$ ) 'pertaining to the chin' $(O E D)$, but tan and pan, den and men, fin and sin, etc.). It can however be seen that much depends on the criteria used to establish this kind of class. For instance, if a criterion of semantic identity rather than notional identity were used, it is clear that the meaning of 'mouth', 'the opening in the head of a person or animal through which food is ingested and vocal sounds emitted' ( $\mathrm{gam}$ ) and 'throat', 'the front of the neck beneath the chin and above the collar-bones' (gan) would not allow these two items to be grouped together on the basis of semic commonality, unless evidence provided by polysemy were also taken into account (e.g. gam (n.) 'large teeth, tusks, the mouth, the lips'), gan (n.) 'the mouth, the throat, ( $p l$.) the gums, the jaws').

\begin{tabular}{|c|c|c|c|}
\hline $\begin{array}{l}\text { 'gVC(-) } \\
\text { words' }\end{array}$ & $\begin{array}{l}\text { Meaning(s) referring to } \\
\text { jaw-related phenomena } \\
\text { (n.) }\end{array}$ & $\begin{array}{l}\text { Meaning(s) referring } \\
\text { to } \\
\text { jaw-related } \\
\text { phenomena } \\
\text { (v.) }\end{array}$ & Etymology \\
\hline gam & $\begin{array}{l}\text { 1. pl. Large teeth, tusks } \\
\text { 2. The mouth }(O E D) \\
\text { The lips }\left(E D D^{I I}\right)\end{array}$ & $\begin{array}{l}\text { To cause teeth to grow } \\
\text { crooked and } \\
\text { overlapping } \\
\text { each other }\left(E D D^{I I}\right)\end{array}$ & ? (cf. PIE * $\hat{g} e m b h-$ 'tooth, nail') \\
\hline gan & $\begin{array}{l}\text { The mouth }(O E D) \\
\text { The throat; } p l \text {. the } \\
\text { gums, also the jaws } \\
\left(E D D^{I I}\right)\end{array}$ & $\begin{array}{l}\text { To stare, gaze vacantly } \\
\left(E D D^{I I}\right)\end{array}$ & $\begin{array}{l}\text { (n.) cf. Sw. (dial.) gan, 'the inner } \\
\text { part of the mouth, the mouth, the } \\
\text { gill of a fish' }\left(E D D^{I I}\right) \\
\text { (v.) cf. Sw. (dial.) gana 'to stand } \\
\text { and wonder at anything' } \\
\left(E D D^{I I}\right) \text {, } \\
\text { cf. ON gan 'yawn; cry' } \\
<\text { PIE * gheh } a_{a^{-}}\end{array}$ \\
\hline gape & $\begin{array}{l}\text { The act of opening the } \\
\text { mouth; a yawn }(O E D)\end{array}$ & $\begin{array}{l}\text { To open the mouth } \\
\text { wide, } \\
\text { esp. in order to bite or } \\
\text { swallow anything } \\
(O E D)\end{array}$ & $\begin{array}{l}\text { (v.) ON gapa 'to open the } \\
\text { mouth' } \\
\text { < PIE * }{ }^{2} e h_{2} i-\text { 'to yawn, gape' } \\
\text { (AHDIER })\end{array}$ \\
\hline gen & $\varnothing$ & $\begin{array}{l}\text { To open, gape; grin, } \\
\text { to show the teeth like }\end{array}$ & $\begin{array}{l}\text { OE geonian (ginian) 'to open the } \\
\text { mouth' }\left(E D D^{I I}\right)<\mathrm{PIE} * \hat{g} h e h_{2} i^{-}\end{array}$ \\
\hline
\end{tabular}




\begin{tabular}{|c|c|c|c|}
\hline & & $\mathrm{a} \operatorname{dog}\left(E D D^{I I}\right)$ & 'to yawn, gape' (EIEC) \\
\hline $\begin{array}{l}\text { gen- in } \\
\text { genial }\end{array}$ & $\begin{array}{l}\left.\text { (adj. }{ }^{2}\right) \text { Of or pertaining } \\
\text { to the chin }(O E D)\end{array}$ & $\varnothing$ & $\begin{array}{l}\text { Gk. genus 'jaw, chin' } \\
<\mathrm{PIE} * \text { genu- 'jawbone, chin' } \\
(\text { AHDIER })\end{array}$ \\
\hline gill & $\begin{array}{l}\text { The lower jaw, the flesh } \\
\text { under the chin or ears; } \\
\text { the mouth, throat } \\
\left(E D D^{I I}\right) \text {; } \\
\text { the organ of respiration } \\
\text { in } \\
\text { fishes... }(O E D)\end{array}$ & $\begin{array}{l}\text { 1. To gut or clean (fish) } \\
\text { 2. To handle the gills of, } \\
\text { take hold of by the gills } \\
(O E D)\end{array}$ & $\begin{array}{l}\text { (n.) Middle Eng. gile, gill, from } \\
\text { a } \\
\text { Scandinavian source akin to ON } \\
*_{\text {gil, gill of a fish }<\text { Germ. *geliz }} \\
<\quad \text { PIE *ghel-unā- 'jaw' } \\
(\text { AHDIER })\end{array}$ \\
\hline gip & $\begin{array}{l}\text { The point of the jaw of a } \\
\text { fish }\left(E D D^{I I}\right)\end{array}$ & $\begin{array}{l}\text { To open the mouth for } \\
\text { want of breath }\left(E D D^{I I}\right) \text {; } \\
\text { to clean (fish) for curing } \\
(O E D)\end{array}$ & $\begin{array}{l}\text { (n.) Compare Sw. (mun) gipa, } \\
\text { corner of the mouth }\left(E D D^{I I}\right) \\
\text { (v.) Origin unknown }(O E D)\end{array}$ \\
\hline$g o b$ & $\begin{array}{l}\text { The mouth }(O E D) \\
\text { A beak }\left(E D D^{I I}\right)\end{array}$ & To spit $(O E D)$ & $\begin{array}{l}\text { (n.) OF gobe, goube 'mouthful, } \\
\text { lump' < gober 'swallow, gulp' } \\
(?<\text { Celt. *gobbo 'mouth, beak', } \\
\text { whence prob. Sc. and north. } \\
\text { Eng. gob mouth, ODEE) }\end{array}$ \\
\hline gum & $\begin{array}{l}\text { The firm fleshy } \\
\text { integument of the jaws } \\
\text { and bases of the teeth } \\
(O E D)\end{array}$ & $\begin{array}{l}\text { To deepen and enlarge } \\
\text { the spaces between the } \\
\text { teeth of (a worn saw) } \\
(O E D)\end{array}$ & $\begin{array}{l}\text { OE gōma 'palate, jaw' } \\
<\text { Germ. gō-ma } \\
<\text { PIE * } \hat{g} h \bar{e} u \text { - 'to yawn, gape' } \\
(\text { AHDIER })\end{array}$ \\
\hline $\begin{array}{l}\text { gur- in } \\
\text { gurgitate }\end{array}$ & $\begin{array}{l}\text { (gurgitation) } \\
\text { 'swallowing; } \\
\text { guzzling' }(O E D)\end{array}$ & $\begin{array}{l}\text { To swallow greedily or } \\
\text { immoderately }(O E D)\end{array}$ & $\begin{array}{l}\text { Lat. gurges 'throat' < } \mathrm{PIE}^{*} g^{w} r \neq- \\
g- \\
<\quad * g^{w} \operatorname{erh}_{3^{-}} \quad \text { 'to swallow' } \\
(\text { AHDIER })\end{array}$ \\
\hline
\end{tabular}

Fig. 5: English ' $g V C(-)$ words' referring to jaw-related phenomena Sources: $O D E E^{169}, O E D, E D D, A H D I E R^{170}, E^{1 E} C^{171}$

It may be noted in passing that colloquial and dialect French also has a small number of etymologically unrelated ' $g n$ - words' denoting jaw-related phenomena, in which $g n$ - is pronounced /n/, e.g. gnaquer (v.) 'to bite (into)', gnaques (n. pl.) 'the teeth (of a dog)', gnagne (n.) '(large molar) tooth', gnigue-gnaque (n.) 'said of the movement of the teeth when chewing', and gnac (n.) 'bite' (cf. metaphorical uses such as 'avoir du gnac' or 'avoir la gnaque'), all late, onomatopœic formations. Modern French also has a few 'gn- words' whose meanings do not seem to be jaw-related, in which $g n$ - is pronounced /gn/. These are either borrowings, e.g. from Italian, gnocchi (1864) or, from Hottentot, gnu (1778), or of Greek and/or Latin origin, e.g. gnome (1583), built to Gk. gnôme, and (also Lat.) gnomon (1547). This paucity is scarcely surprising since, as Ernout \& Meillet state (2001: 278) with reference to gnārus, gn- was not preserved in Latin, while in Ancient Greek, apart from a few derivatives, one only finds $\gamma v \alpha \dot{\theta} \theta \varsigma_{\varsigma}$ 'jaw' ( $<\mathrm{PIE} * \hat{g} e n u$ - 'jawbone, chin') and $\gamma v \alpha \dot{\alpha} \mu \pi \tau \omega$ 'to curve, bend', of uncertain etymology (Chantraine 1999: 230). As for the lexical schema GVN(-), Modern French has ganache (< Ital. ganascia 'jaw') ' \pm lower jaw (of a horse)', gencive (n.) 'gum', and gingival (adj.) 'relative to the gums'. While ganache appears to be

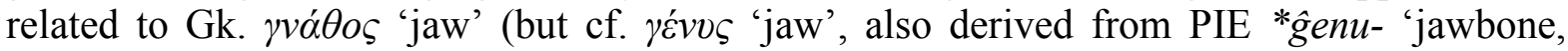
chin'), gencive and gingival can be traced back to Lat. ğniva, whose form may display a trace of reduplication ( $*_{\text {gen- }}$-īua $)$ according to Ernout \& Meillet (2001: 275).

\footnotetext{
${ }^{169}$ The Oxford Dictionary of English Etymology (Onions 1966).

${ }^{170}$ The American Heritage Dictionary of Indo-European Roots (Watkins 2000).

${ }^{171}$ Encyclopedia of Indo-European Culture (Mallory \& Adams 1997).
} 


\section{Core invariance in Proto-Indo-European}

As seen above, data furnished by $E D D$ and $O E D$ provide evidence of a notional link between the class of ' $g n$ - words' denoting jaw-related phenomena such as mastication (e.g. gnaw), manducation (e.g. gnip), manners of speaking (e.g. gnap) and expressive gestures with bared teeth (e.g. gnarl) and that of ' $g V n(-)$ words' denoting jaw-related phenomena. In the lexical schema underlying the ' $g n$ - words' in fig. 1, i.e. $G N V C(-), G N$ - has been identified as a core invariant, while in that underlying the ' $g V n(-)$ words' in fig. 5, i.e. $G V N(-)$, $G$ seems to function as a core invariant. Now if one accepts Benveniste's reconstruction of the canonical form of the IE root as $C_{1} e C_{2}$ with two alternating thèmes or 'bases' (1935: 170), then it becomes apparent that English ' $g V n(-)$ words' denoting jaw-related phenomena are modelled on base I (full grade) of the root $\left({ }^{*} C V C\right.$-), while ' $g n$ - words' referring to the same notional domain are modelled on base II (zero grade, ${ }^{*} C C V$-). Also, the derivatives of one and the same PIE root form may be represented by both schemas in English, e.g. GVN(-) in genial 'of or pertaining to the chin', and GNVC(-) in gnathic 'of or pertaining to the jaws'

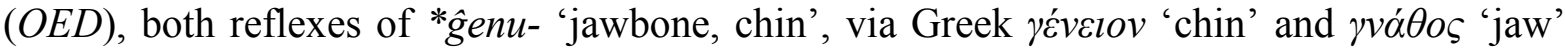
respectively.

Furthermore, according to one of the principles set out in Grimm's Law, initial /g/ devoices to /k/ between Indo-European and Proto-Germanic (Szemerényi 1999: 17), while normally remaining voiced in Latin and Greek (Beekes 1995: 110). This helps to explain why the two lexical schemas corresponding to PIE * $g$ ^enu- 'knee', namely GVN(-) (base I) and $G N V C(-)$ (base II), are in complementary distribution in Eng. genuflexion (n.) and knee (n.): whereas the former continues, via late Latin, the $G V N(-)$ base I schema, the latter continues, via Germanic, the GNVC(-) base II schema, becoming KNVC(-) in Late Modern English.

Now there is structural evidence in PIE which suggests that in certain 'root doublets', the consonant occupying the $C_{1}$ slot in the canonical root structure $C_{1} e C_{2}$ functions as a core invariant, and $C_{2}$ as a variable. This evidence comes in two forms. The first of these is rootfinal $*_{-r}-/ *_{-}-$- alternation (Benveniste 1964: 25) that does not correlate with a change in the underlying notion conveyed by the root, as in *gal-/*gar- 'to call, shout', * $\hat{g h e l-/ *}$ gher- 'to shine', *ghel-/*gher- 'to call (out)', *pel-/*per- 'to strike', *(s)kel-/*(s)ker- 'to cut', *wel$1 *$ wer- 'to turn', etc., while the second is root-final voiced/voiceless alternation that, like *-r$/ *-l$ - alternation, does not correlate with a change in the underlying notion, e.g. *peig-/*peik'to cut, mark', or * $\hat{g} e b h-/ * \hat{g e p h}$ - 'jaw, \pm eat', etc.

If the consonants occupying the $C_{1}$ slot in the abovementioned PIE 'root doublets' with initial $* \hat{g} h-,{ }^{*} g h$ -,${ }^{*} \hat{g}$ - or $* g$ - function as core invariants, and those occupying the $C_{2}$ slot $\left({ }^{*}-r-\right.$ $\left./ *_{-} l-, *_{-} g_{-} / *_{-} k_{-}, *_{-} b h-/ *_{-} p h-\right)$ as variables, then it is conceivable that the root-final consonants in other roots with initial $* g h-, * \hat{g} h$-, $* \hat{g}$ - or $* g$ - whose derivatives denote jaw-related phenomena also function as variables, since they too enter into a relation of alternation which does not correlate with a change in the underlying notion conveyed by the root. Examples include * $\hat{\text { gembh}}$ - 'tooth, nail' (> Eng. comb), * $\hat{g}_{h} h_{2}{ }_{2}$ - 'to yawn, gape' (> Eng. gape), *ghel$u n \bar{a}-$ 'jaw' (> Eng. gill), the hypothetical roots * $g(e) n$ - 'to compress into a ball' (> Eng. gnarl) and *gh(e)n- 'to gnaw' (> Eng. gnaw), * genu- 'jawbone, chin' (> Eng. gnathic), and *gheh $h_{a}(u)-m r$ - 'interior of mouth (e.g. gums, palate)' (> OE gōma 'inside of mouth or throat', Mod. Eng. gum). 


\section{Conclusion: submorphemic iconicity in English 'gn- words'}

To account for the dyadic relation $\{<\mathrm{gn}->$, /jaw-related phenomena/ $\}$ that can be traced back, through Germanic or Hellenic, to Proto-Indo-European, two types of explanation are possible. One holds that since the linguistic sign has no natural connection with the referent, acquiring its value solely as a result of the differential, language-internal relations it maintains simultaneously with other, like signs in the system, it is senseless to identify possible links between the extralinguistic and the linguistic: as conceived by Saussure, the linguistic sign is, by definition, arbitrary. A second type of explanation has it that the sign has become arbitrary, implying that it enjoyed, at some emergent stage in the evolution of language, a partly natural relation with the extralinguistic. Of course, this stance has its problems, insofar as it is neither demonstrable nor falsifiable; furthermore, much depends on what is meant, exactly, by 'natural'. Whatever the case, the hypothesis proposed below provides a possible account of this relation.

The sublexical marker $<\mathrm{g}>$ assumed to function as a core invariant in the $C_{l}$ slot of the above-mentioned PIE 'root doublets' and other roots with initial $* g h-, * \hat{g} h-,{ }^{*} \hat{g}_{-}$, or ${ }^{*} g-$ whose derivatives have meanings referring to jaw-related phenomena such as sound articulation, mastication and manducation, is realized phonetically as a voiced velar occlusive, whether aspirated, e.g. *gh- in *gh(e)n- 'to gnaw', aspirated and palatalized, e.g. $\hat{g} h$ - in ${ }^{*} \hat{g} h e h_{2} i$ - 'to yawn, gape', palatalized, e.g. * $\hat{g}$ - in * $\hat{g} e n u$ - 'jawbone, chin', or not, e.g. * $g$ - in * $g e h_{1} i$ - 'to sing'.

By reanalysing this root-initial occlusive as a gesture of occlusion (Browman \& Goldstein 1992: 156), and hypothesizing that it originally served, because of its occlusive quality, as an articulatory unit around which forms with meanings related to the goal-orientated, occlusive (open-close) mandibular movements involved in oral activities such as gnawing and primitive calling could be constructed, we may trace it back to a possible scenario of the emergence of human speech similar to that described by MacNeilage in his "Frame-Content Theory" (1998, cf. also MacNeilage 2008: Part V). MacNeilage sees the open-close mandibular cycle as the main articulatory 'building block' of speech production, and the evolution of the open-close alternation of the mouth for purposes of speech as "the tinkering of an already available motor cyclicity into use as a general purpose carrier wave for timeextended message production." (1998: 506).

In other words, I posit that the naturally occlusive properties of the various phonetic realizations of $\langle\mathrm{g}>$ originally endowed it with the capacity to refer back to the jaws, both metonymically - the (articulated) sound for the articulators-and iconically, in that the sign thus created partakes in the character of its object (Peirce 1991: 251). Evidence from IndoEuropean languages suggests that this putative self-referential capacity may have been extended, again by metonymical association (part/whole, interior/exterior, contiguity, etc.), to signs denoting the jaw's physiological environment (chin, mouth, cheeks, teeth, gums, palate...), its movements (biting, gnawing, eating, swallowing...), and its expressive connotations (to gape ['an open-mouthed stare'], to gaze [to stare (at)], to stare ['to gaze fixedly and with eyes wide open]...), etc. The evolution of occlusions from the non linguistic to the linguistic, via the prelinguistic, may be modelled schematically as follows: 


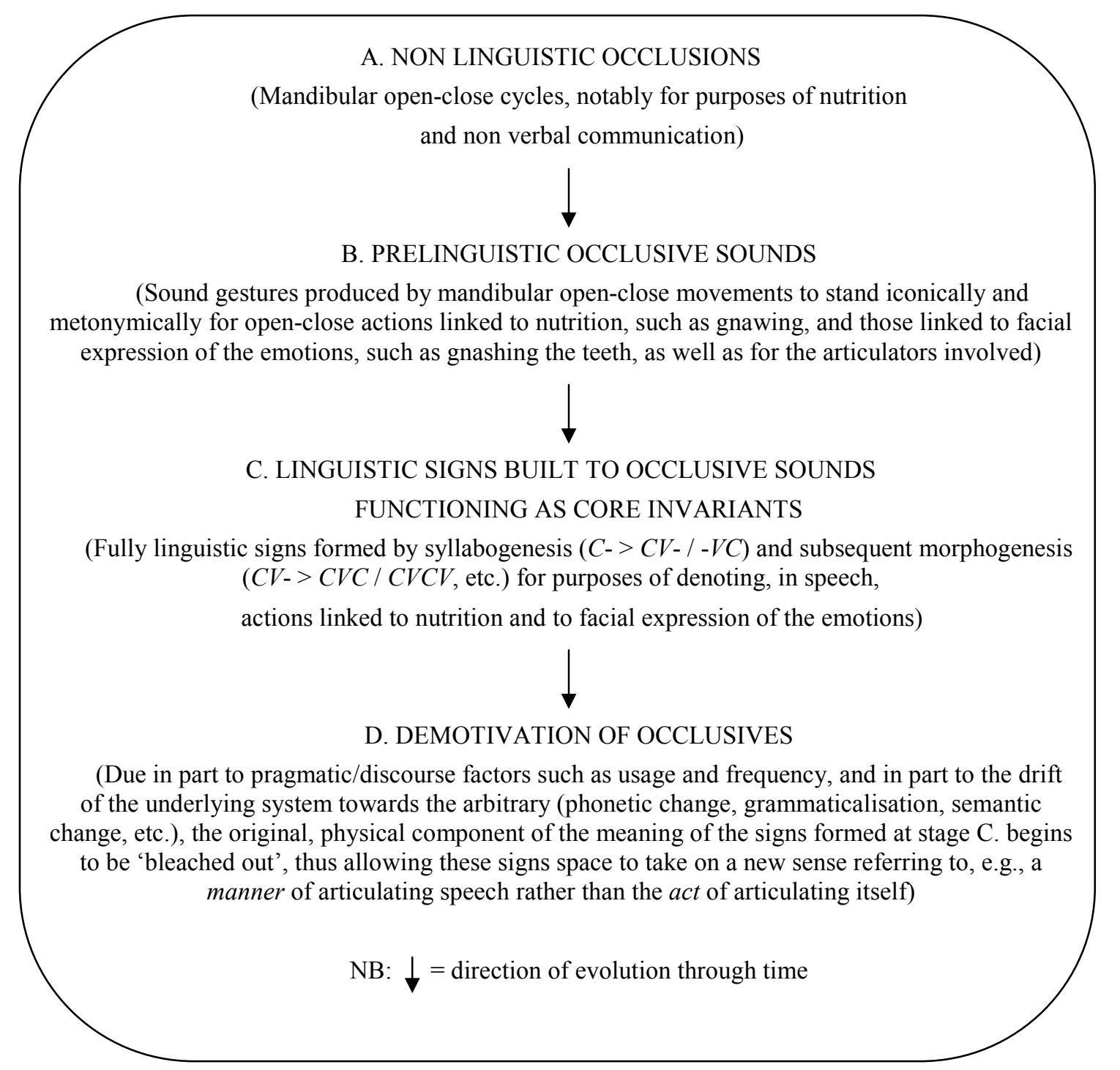

Fig. 6: Modelling the emergence and evolution of the sign

Hence, several millennia later, the meanings of English ' $g n$-' and ' $g V n(-)$ ' words referring to jaw-related phenomena (and also words having undergone affrication such as jowl, $<\mathrm{OE}$ cēafl 'jaw, cheek' < Germ. *kêfalaz < PIE * $\hat{g} e b h-/ * \hat{g} e p h$ - 'jaw, \pm eat' and chin, < OE $\operatorname{cin}(n)<$ Germ. *kinnuz < PIE * $\hat{g}$ enu- 'jawbone, chin') would to some extent be predetermined by this causally based, self-referential capacity. However, this does not imply that such a possibility is necessarily materialized in any language, or that any realization of $<\mathrm{g}>$, irrespective of its position, must actualize this potential. In Indo-European, for instance, ${ }^{*}-\hat{g} h$ - may function as a root extension (e.g. *bhelgh- 'to swell' <*bhel-, Rix et al. 2001: 73-74), irrespective of the notion conveyed by the root in which it occurs.

While reconciling these two types of explanation appears impossible, it may nevertheless be adduced that whereas English ' $g n$ - words' and ' $g V n(-)$ words' with jaw-related meanings are arbitrary at the morphemic level, they may be partially non-arbitrary at the submorphemic level. This would be so if the words in question were construed as being built to a core invariant $(\langle\mathrm{g}\rangle)$ which originally possessed an inherent, self-referential value that gradually became more and more arbitrary as linguistic processes such as phonetic change (recall that 
/g/ in words beginning with $g n$ - is no longer realized phonetically in Late Modern English) and structural evolution ( $g n$ - no longer appears to be functionally divisible in English) modified the original, semiogenetic conditions of the transformation of the sign from prelinguistic to linguistic status. If this postulate is admitted, then it may be concluded that a trace of submorphemic iconicity persists in English ' $g n$-' and ' $g V n(-)$ ' words denoting jawrelated phenomena.

\section{References}

BeEkes, Robert S. P., 1995. Comparative Indo-European Linguistics. An Introduction. Amsterdam / Philadelphia: John Benjamins.

BENVENISTE, Émile, 1964 [1939]. «Répartition des consonnes et phonologie du mot». In Études phonologiques dédiées à la mémoire de M. le Prince N. S. Trubetzkoy. Alabama: University of Alabama Press, 27-35.

BERGEN, Benjamin K., 2004. "The psychological reality of phonæsthemes". Language 80 (2), 290-311.

BLOOMFILED, Leonard, 1933. Language. London: Allen \& Unwin.

Bolinger, Dwight L., 1949. "The sign is not arbitrary". Boletín del Instituto Caro y Cuervo $5,52-62$.

---, 1950. "Rime, assonance and morpheme analysis". Word 6 (2), 117-136.

Bottineau, Didier, 2003. "Iconicité, théorie du signe et typologie des langues ». In Le mot comme signe et comme image : lieux et enjeux de l'iconicité linguistique, Cahiers de linguistique analogique 1, Philippe Monneret (Ed.). Dijon: ABELL, 209-228.

Browman, Catherine P., \& Goldstein, Louis M., 1992. "Articulatory phonology: an overview". Phonetica 49, 155-180.

Chantraine, Pierre, 1999 [1968]. Dictionnaire étymologique de la langue grecque. Paris: Klincksieck.

CRYSTAL, David, 2003. A Dictionary of Linguistics \& Phonetics, $5^{\text {th }}$ edition. Oxford: Blackwell.

Culioli, Antoine, 1990. Pour une linguistique de l'énonciation. Opérations et représentations, vol. 1. Gap: Ophrys.

DoBSON, Eric J., 1968 [1957]. English Pronunciation 1500-1700, $2^{\text {nd }}$ edition, 2 vols. Oxford: Clarendon.

ERnout, Alfred, \& MeILlet, Antoine, 2001 [1932]. Dictionnaire étymologique de la langue latine. Reprint of the revised $4^{\text {th }}$ edition. Paris: Klincksieck.

FIRTH, John R., 1930. Speech. London: Ernest Benn.

Guillaume, Gustave, 1964. Langage et science du langage. Paris: A.-G. Nizet / Quebec: Les Presses de l'Université Laval.

---, 1984. Foundations for a Science of Language (translated by W. Hirtle and J. Hewson). Current Issues in Linguistic Theory, vol. 31. Amsterdam: John Benjamins.

HiRTLE, Walter, 2007. Language in the Mind. An Introduction to Guillaume's Theory. Montreal: McGill-Queen's University Press. 
JESPERSEN, Otto, 1994 [1905]. Growth and Structure of the English Language, $10^{\text {th }}$ edition. Oxford: Blackwell.

KÖKERITZ, Helge, 1945. "The reduction of initial $k n$ and $g n$ in English". Language 21 (2), 77-86.

LADEFOGED, Peter, 2005. Vowels and Consonants. $2^{\text {nd }}$ edition. Oxford: Blackwell.

LUTZ, Angelika, 1992. "Lexical and morphological consequences of phonotactic change in the history of English". In History of Englishes: New Methods and Interpretations in Historical Linguistics, Matti Rissanen, Ossi Ihalainen, Terrtu Nevalainen, \& Irma Taavitsainen (Eds.). Berlin / New York: Mouton de Gruyter, 156-166.

MaCNEILAGE, Peter F., 1998. "The frame/content theory of evolution of speech production". Behavioral and Brain Sciences 21, 499-546.

---, 2008. The Origin of Speech. Oxford: Oxford University Press.

Mallory, James P., \& ADAMS, Douglas Q. (Eds.), 1997. Encyclopedia of Indo-European Culture. London and Chicago: Fitzroy Dearborn.

OnIONS, Charles T. (Ed.), 1966. The Oxford Dictionary of English Etymology. Oxford: Clarendon Press.

PEIRCE, Charles S., (1991 [1906]). "Prolegomena to an apology for pragmaticism". In Peirce on Signs, J. Hoopes (Ed.). Chapel Hill: The University of North Carolina Press, 249252.

PHILPS, Dennis, 2002. «Le concept de 'marqueur sub-lexical' et la notion d'invariant sémantique ». In La notion d'invariant sémantique, P. Larrivée (Ed.). Travaux de linguistique 45, 103-123.

---, 2003. «S- incrémentiel et régénération submorphémique en anglais ». Bulletin de la Société de Linguistique de Paris XCVIII (1), 163-196.

POKORNY, Julius, 1959. Indogermanisches etymologisches Wörterbuch, 2 vols. Bern and Munich: Franke.

RiX, Helmut (Ed.), KüMMEL, Martin, ZEHNDER, Thomas, LiPP, Reiner \& SCHIRMER, Brigitte, 2001. Lexikon der indogermanischen Verben. Wiesbaden: Reichert.

Southern, Mark R. V., 1999. Sub-Grammatical Survival: Indo-European s-mobile and its Regeneration in Germanic. Washington DC: JIES 34 / Institute for the Study of Man.

SZEMERÉNYI, Oswald J. L., 1999. Introduction to Indo-European Linguistics. Oxford: Oxford University Press.

Trask, R. L., 1996. A Dictionary of Phonetics and Phonology. London: Routledge.

WAtKIns, Calvert, 2000. The American Heritage Dictionary of Indo-European Roots, $2^{\text {nd }}$ edition. Boston: Houghton Mifflin.

Wright, Joseph (Ed.), 1898-1905. The English Dialect Dictionary, vols. I-VI. London: H. Frowde. 